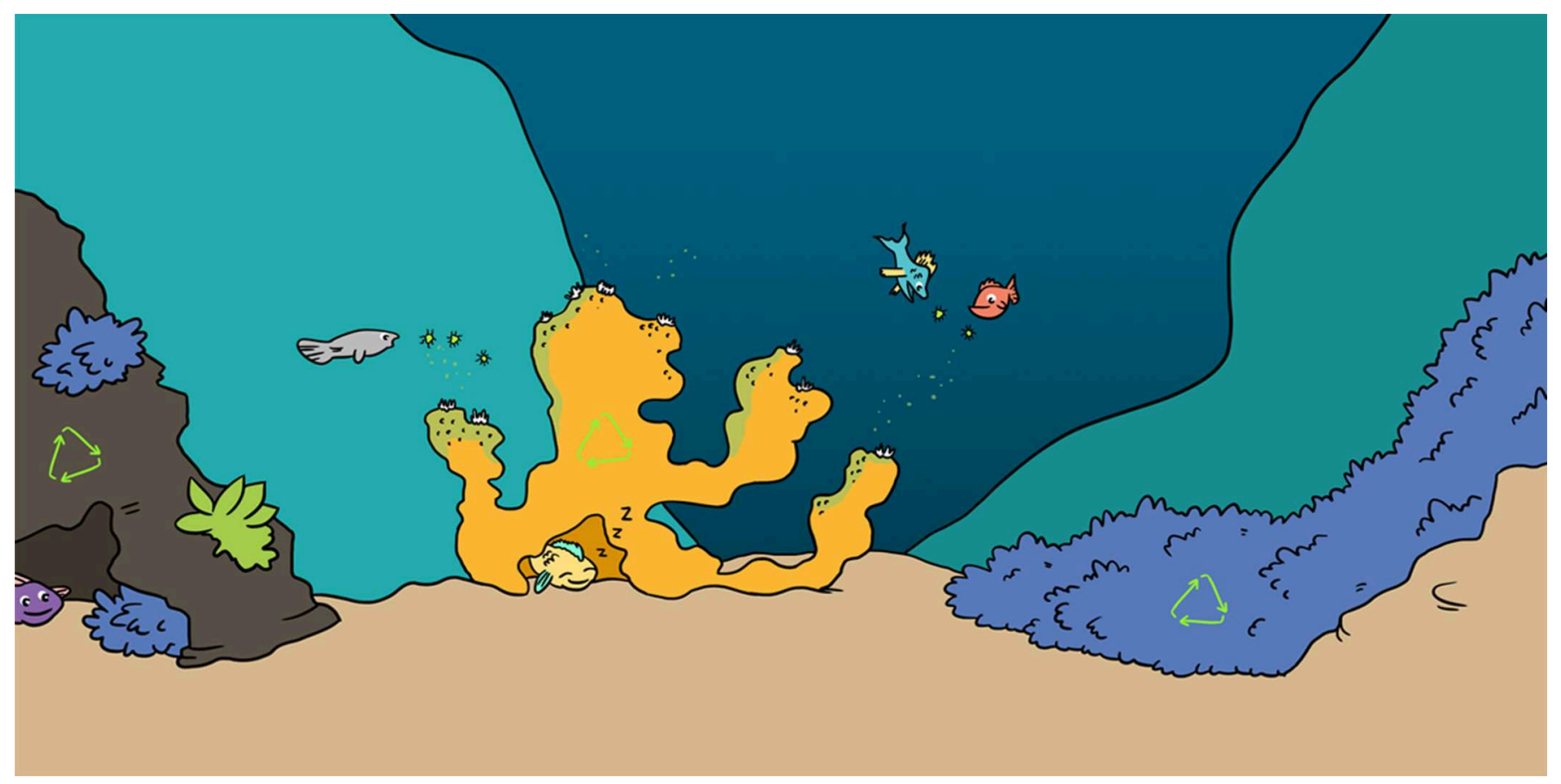

\title{
WHY ARE CORAL REEFS HOTSPOTS OF LIFE IN THE OCEAN?
}

\section{Nils Rädecker * and Claudia Pogoreutz}

Biological and Environmental Science and Engineering Division, Red Sea Research Center, King Abdullah University of Science and Technology, Thuwal, Saudi Arabia

YOUNG REVIEWERS:

ABRAHIM

The tropical ocean contains very little food or nutrients. Like life in a desert, life in the tropical ocean is difficult for all organisms. Yet, coral reefs are colorful oases full of life in the middle of this marine desert. How can millions of species call coral reefs their home? All organisms living there play their roles in recycling the small amounts of food and nutrients that are available. Because nothing is ever truly wasted, coral reefs can flourish in a marine desert that has hardly any food. Although coral reefs existed on this planet long before the dinosaurs, they are facing serious problems today. Warming oceans can harm corals, leading to the loss of coral reefs. However, corals in the northern Red Sea are very resistant to warm temperatures. Some scientists believe that these Red Sea reefs may be able to survive even when reefs are disappearing elsewhere around the world. 


\section{NUTRIENT}

A substance required for the survival and growth of an organism.

\section{SYMBIOSIS}

Two different organisms living in a close relationship. In the case of corals, both corals and their algae benefit from the symbiosis. However, not all symbiotic relationships are good for all organisms. Parasitic tapeworms, for example, live in the gut of other organisms and steal food and nutrients from them.

\section{PHOTOSYNTHESIS}

A process by which green plants and algae produce their own food. In this process, the energy of the sunlight is used to make sugars from carbon dioxide $\left(\mathrm{CO}_{2}\right)$ and water $\left(\mathrm{H}_{2} \mathrm{O}\right)$.

\section{OASES IN A MARINE DESERT}

Every living creature needs energy and nutrients to live and grow. Because of this, organisms living in places where food and nutrients are scarce need to be creative to survive. Similar to deserts on land, the tropical ocean is very low in food and nutrients. This is also the reason why the tropical ocean appears so clear and blue: very few creatures grow there. Yet, coral reefs form vibrant, colorful oases full of life-right in the middle of these ocean deserts. Although coral reefs only cover a very small part of the seafloor in the tropical ocean, they are home to a quarter of all known marine species. Coral reefs are also very important for millions of people, because fishes and other reef animals are important food sources, and the reefs themselves help protect coasts from storms and waves.

The famous scientist and explorer Charles Darwin was one of the first to wonder how so many different animals and plants could live in coral reefs even though the surrounding water contains so little food and nutrients [1]. Now, after more than a century, scientists are finally beginning to understand this so-called "Darwin Paradox." In this article, we look at how millions of species of coral, fishes, invertebrates, algae, and microorganisms each play their role in making coral reefs true oases in the marine desert.

\section{CORALS: ENGINEERS OF THE REEF}

There would not be coral reefs without stony corals. Corals are very different from most animals, because they grow attached to the seafloor and live in colonies. Each colony is made up of thousands of little animals, called polyps. Every polyp has its own mouth and tentacles to catch food, like the tiny shrimp and worms swimming in the sea. Together, these polyps build a skeleton made of limestone, so that they can grow and be protected from predators. Over hundreds to thousands of years, these skeletons grew into the massive underwater structures that form the coral reefs we see today (Figure 1).

Like all other animals, corals need food and nutrients to grow and also to build reefs. So, how do corals survive and grow in an ocean where there is hardly any food to catch? The answer is as fascinating as it is simple: they can grow their own food! This is because corals live in symbiosis with other organisms in and on the coral's body, like bacteria, algae, and fungi. These symbiotic relationships are very important to keep the coral animal fit and healthy. For example, corals form a very special partnership with tiny algae that live within the cells of the coral. These algae can perform photosynthesis, a process by which the algae capture light energy from the sun and use that energy to turn carbon dioxide $\left(\mathrm{CO}_{2}\right)$ into sugars. The sugars are their source of energy. The algae produce so much sugary food that they can even share a large part of it with the coral. As the corals consume the sugars, 
Figure 1

Coral reefs in the Red Sea are colorful and full of life. These reefs are home to millions of species, from tiny bacteria to sharks. Coral reefs are built from the limestone skeletons of corals. Each coral consists of hundreds to thousands of animals. These animals are called polyps. The polyps live together in one colony Each polyp has a mouth and tentacles to catch food from the ocean. In addition, small algae living inside the corals produce sugars as food for themselves and the coral. Photo credit: Tane Sinclair-Taylor.

\section{FOOD WEB}

The connections between organisms, in terms of how they get their food and nutrients and how they pass food and nutrients on to other organisms.

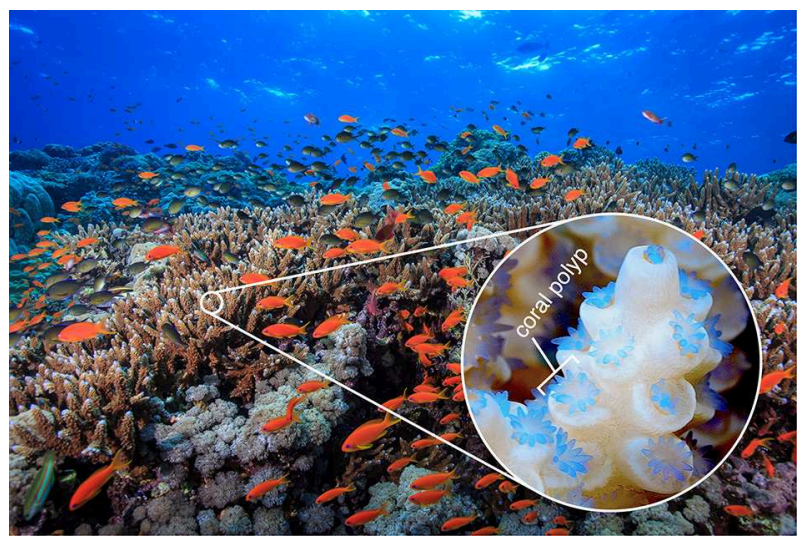

Figure 1

they produce more $\mathrm{CO}_{2}$ for the algae. This exchange of sugars and $\mathrm{CO}_{2}$ between the coral and their algae allows these symbiotic partners to efficiently recycle energy and nutrients (Figure 2A). Therefore, corals do not need to catch much prey from seawater [2]. This powerful partnership between corals and tiny algae is the reason why coral reefs have survived on this planet for hundreds of millions of years. Over time, the coral reefs continue to grow. Today, some coral reefs are so large they can even be seen from space, like the 2,300 km long Great Barrier Reef in Australia.

\section{WHO EATS WHOM ON THE CORAL REEF?}

Corals and algae are not the only organisms living on corals reefs. Millions of other species of animals, plants, and microbes call reefs home, too. Unlike corals, most creatures on a coral reef do not live in a symbiosis with little algae that produce sugar for them. They need to find their own food. So how do all these species survive, if there are so few nutrients in the surrounding water? Similar to the partnership between corals and their algae, food and nutrients are efficiently recycled over and over again on the entire coral reef. The food web of coral reefs is so complex that nothing is ever wasted: one creature's leftovers are a feast for another creature (Figure 2B). Corals and their algae are part of the fuel that drives the coral reef food web. The algae produce so much sugar that not even the coral can eat all of it. The left-over sugar that the coral will not eat is used to produce a slimy mucus. Some of the mucus covers the coral and helps protect it from diseases or from drying out during low tide. But a lot of the mucus ends up in the seawater, too. Because the mucus contains a lot of sugar, bacteria and other microbes eat it. The bacteria in turn get eaten by small critters, like crabs, shrimp, snails, and worms living in the water or on the seafloor. Next, reef fishes feed on these small organisms. At night, the fishes rest and sleep, well-hidden in the branches of the coral. As the fish digest the foods they have eaten, they eventually poop. The poop returns nutrients into the seawater 
around the coral. These nutrients are quickly taken up again by algae within the coral, helping them grow and perform photosynthesis. In this way, the feeding and pooping of many animal species on the reef creates an endless loop, in which nutrients are re-used [3]. With so many different species feeding and pooping on a coral reef, there are many endless nutrient loops, recycling food so efficiently that hardly any nutrients are ever lost. This is why millions of species on a coral reef can survive, even though the seawater around them contains so little food.

\section{CORAL REEFS IN DANGER}

Coral reefs have lived in the tropical oceans for hundreds of millions of years. Recently, however, increasing numbers of coral reefs around the world have started to die and disappear. The reason behind this ultimately boils down to growing human populations [4]. People use coral reefs as food sources. With more and more people living close to coral reefs, a lot of fish are taken from the reefs. As a consequence, many coral reefs are badly overfished. With fewer and smaller fish on the reefs, the feeding and pooping loops are disturbed, which changes the re-use of food and nutrients. Also, because there are fewer algae-eating fish, these fish cannot keep the algae in check. Some of these algae can then overgrow and harm corals.

However, the greatest problem for coral reefs is climate change [4]. Climate change makes the oceans warmer. While corals like tropical warm waters, they do not like it too warm. When the sea around corals gets too warm, the tiny symbiotic algae inside the coral will provide less or no sugars to the coral. In addition, the algae will also produce substances that may damage the tissues of the coral. Thus, the algae are no longer helpful for the coral when the water gets too warm, so the coral has no other choice but to get rid of these algae by releasing them into the sea. Without the tiny algae inside, the corals lose their colorful appearance and the white skeleton inside corals becomes visible. This is called coral bleaching. Without the algae, the bleached coral is also cut off from its main food supply: the sugars made by the tiny algae. Bleached corals, therefore, become weak very quickly, and will eventually starve and die if the water stays too warm for too long [4].

However, it is not just the corals that have a problem when the ocean gets too warm. Without corals, all the other species living on coral reefs lose their homes as well. As a result, entire coral reef ecosystems are slowly disappearing worldwide. This directly affects the lives of many people who depend on healthy coral reefs: fishermen have fewer fish to catch and fewer tourists come to see the reefs. Without healthy coral reefs, fishermen, hotel managers, diving instructors, and many other people could lose their jobs and income. Thankfully, there are many ways to protect coral reefs. For example, fishing bans can help 
Figure 2

Corals reefs are full of life because they very efficiently recycle the small amount of food and nutrients available in the tropical ocean.

(A) Corals and the algae living inside the corals help each other. The algae produce sugar, which the corals eat. In digesting the sugar, corals produce $\mathrm{CO}_{2}$, which can be used by the algae to produce more sugar. (B) Corals also support other reef organisms. The nutrients corals release are eaten by bacteria and other small organisms, and these organisms are then eaten by larger organisms. The poop from the larger organisms returns nutrients to the environment. In this way, food and nutrients are recycled in the complex food web of the reef.
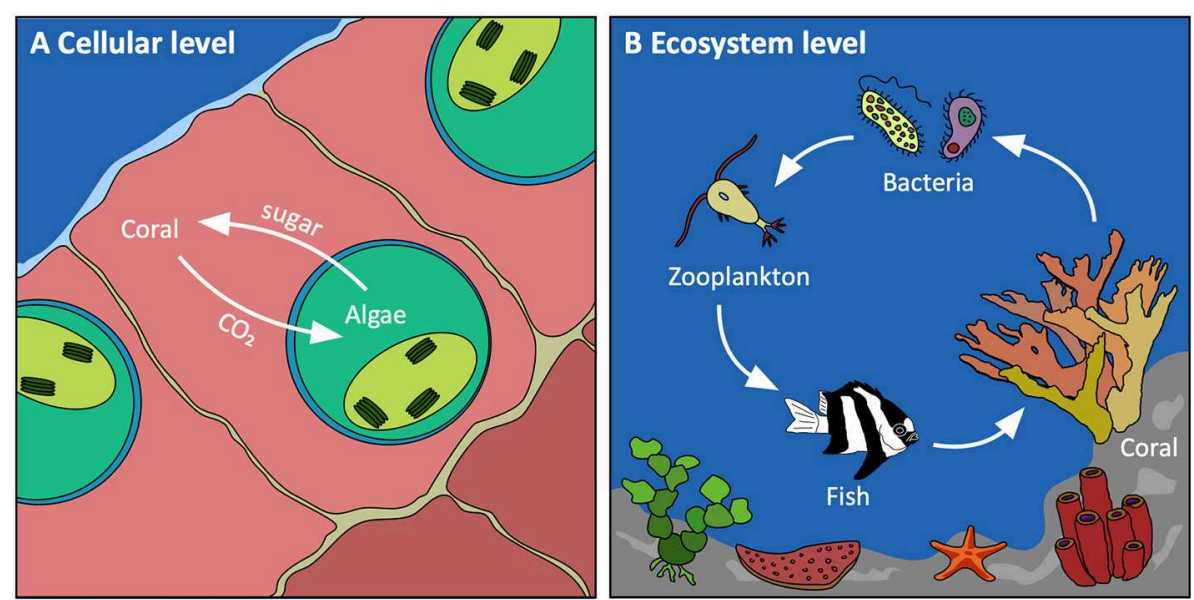

Figure 2

create safe areas for fish to grow. This way, future generations will also be able to catch fish on coral reefs.

\section{ARE RED SEA CORAL REEFS TOUGHER THAN OTHER REEFS?}

The Red Sea is one of the hottest seas on our planet and is very low in nutrients. Even under these extreme conditions, vibrant coral reefs can be found along nearly the entire Red Sea coast. Red Sea coral reefs are very different from most other reefs around the world. Many of the species found on Red Sea reefs can be found nowhere else on the planet. Further, while most other corals bleach when seawater temperatures go higher than $30^{\circ} \mathrm{C}$, corals in the northern Red Sea survive warmer temperatures without bleaching. Scientists from around the world are currently trying to find out why these Red Sea corals are so heat resistant. Maybe it is the environmental conditions of the Red Sea that make the corals that live there tougher? Maybe Red Sea corals could be transplanted to other regions, to replace the reefs that have died from ocean warming? While we are only beginning to answer these questions, Red Sea coral reefs promise to be a refuge for many coral species threatened elsewhere [5].

\section{A FUTURE FOR CORAL REEFS}

Coral reefs are fascinating hotspots of life in the ocean. Even after centuries of research, there is still a lot to learn about these reefs. Scientists keep finding new species and even discover coral reefs in places where they never expected them in the first place. However, climate change and overfishing are severe threats to these ecosystems. Therefore, the future of coral reefs will depend on our actions to save them. All of us can help do their part to help protect coral reefs: for example, eating less coral reef fish, recycling plastic waste so it does not end up in the ocean, or reducing energy 
consumption to slow climate change. This way, coral reefs of the future may remain colorful oases full of life in a marine desert.

\section{ACKNOWLEDGMENTS}

First and foremost, we would like to thank the team of young reviewers for their supportive and helpful feedback. We would also like to thank Ruben M. Costa as well as Christian R. Voolstra for initiating and coordinating the Frontiers for Young Minds Red Sea collection. Further, we would like to thank Tane Sinclair-Taylor for providing the stunning photos for this manuscript.

\section{REFERENCES}

1. Darwin, C. 1842. The Structure and Distribution of Coral Reefs. London: Smith, Elder and Co.

2. Muscatine, L., and Porter, J. W. 1977. Reef corals: mutualistic symbioses adapted to nutrient-poor environments. Source Biosci. 27:454-60. doi: 10.2307/1297526

3. Wild, C., Huettel, M., Klueter, A., Kremb, S. G., Rasheed, M. Y. M., and Jørgensen, B. B. 2004. Coral mucus functions as an energy carrier and particle trap in the reef ecosystem. Nature 428:66-70. doi: 10.1038/nature02344

4. Hughes, T. P., Barnes, M. L., Bellwood, D. R., Cinner, J. E., Cumming, G. S., Jackson, J. B. C., et al. Coral reefs in the anthropocene. Nature 546:82-90. doi: 10.1038/nature22901

5. Osman, E. O., Smith, D. J., Ziegler, M., Kürten, B., Conrad, C., El-Haddad, K. M., et al. 2018. Thermal refugia against coral bleaching throughout the northern Red Sea. Glob. Chang. Biol. 24:e474-848. doi: 10.1111/gcb.13895

SUBMITTED: 25 June 2019; ACCEPTED: 27 November 2019;

PUBLISHED ONLINE: 17 December 2019.

EDITED BY: Christian Robert Voolstra, Universität Konstanz, Germany

CITATION: Rädecker N and Pogoreutz C (2019) Why Are Coral Reefs Hotspots of Life in the Ocean? Front. Young Minds 7:143. doi: 10.3389/frym.2019.00143

CONFLICT OF INTEREST: The authors declare that the research was conducted in the absence of any commercial or financial relationships that could be construed as a potential conflict of interest.

COPYRIGHT @ 2019 Rädecker and Pogoreutz. This is an open-access article distributed under the terms of the Creative Commons Attribution License (CC BY). The use, distribution or reproduction in other forums is permitted, provided the original author(s) and the copyright owner(s) are credited and that the original publication in this journal is cited, in accordance with accepted academic practice. No use, distribution or reproduction is permitted which does not comply with these terms. 


\section{YOUNG REVIEWERS}

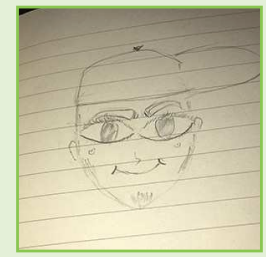

\section{ABRAHIM}

I am your average teenager. I like sports, music, but science has been a passion of mine since I was a child.
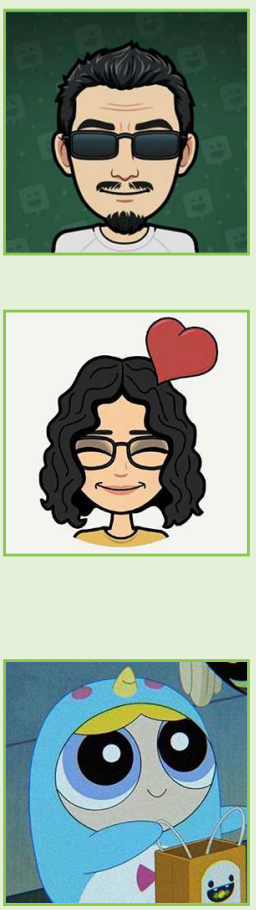

\section{SAMAR}

Someone reading and trying \#reader.

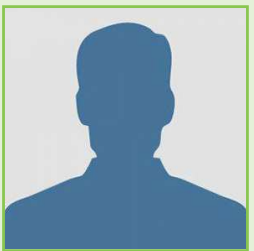

\section{SULTAN}

I love music \#love drawing.

\section{AUTHORS}
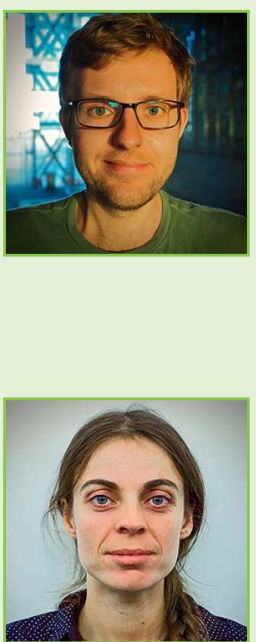

\section{NILS RÄDECKER}

Every time you think you understand something about how nature works, nature has this way of laughing at you and doing the opposite of what you expected. This complexity fascinates me and made me study biology in the first place. For my research, I am working with corals, some of the simplest animals on the planet, to understand the basic processes that help organisms to survive in their environments. ${ }^{*}$ nils.radecker@ kaust.edu.sa

\section{CLAUDIA POGOREUTZ}

Every child has this odd friend who scoops up slugs and worms off a road after a rainfall "to rescue them," or who is intrigued by the strange behavior of a particularly gross critter. I used to be, and still am, this odd friend. Now I am also a post-doctoral researcher working on the diversity and function of microbes in and on marine animals. In particular, I am trying to understand how bacteria help corals in their every-day lives. 